\title{
KAJIAN SOSIOLOGI SASTRA DALAM NOVEL ANAK RANTAU KARYA AHMAD FUADI
}

\author{
Dwi Yuli Hartati \\ Email: dwiyulihartati009@gmail.com
}

\begin{abstract}
Abstrak- Permasalahan penelitian adalah struktur pembangun novel, konteks sosial pengarang, cermin masayakat dalam novel, dan fungsi sosial sastra yang terdapat pada novel Anak Rantau karya Ahmad Fuadi, manfaat penelitian ini menambah pengetahuan mengenai analisis terhadap sastra dan membantu pembaca untuk memahami isi makna yang diungkapkan pada novel Anak Rantau karya Ahmad Fuadi dengan menggunakan kajian sosiologi sastra. Tujuan penelitian untuk mengetahui dan mendeskripsikan struktur pembangun novel, konteks sosial pengarang, sastra sebagai cerminan masayarakat dalam novel dan fungsi sosial sastra pada novel Anak Rantau karya Ahmad Fuadi. Metode penelitian ini adalah metode kualitatif deskriptif. Sumber data penelitian ini adalah novel Anak Rantau karya Ahmad Fuadi. Adapun teknik yang digunakan dalam pengumpulan data penelitian ini menggunakan teknik wawancara dan dokumentasi. Hasil penelitian pada novel Anak Rantau karya Ahmad Fuadi sangat dipengaruhi oleh struktur pembangun novel, konteks sosial pengarangnya, sastra sebagai cerminan masyarakat dan fungsi sosial sastra yang terdapat dalam novel Anak Rantau karya Ahmad Fuadi yang sangat baik.
\end{abstract}

\section{Kata Kunci- Sosiologi sastra, novel Anak Rantau karya Ahmad Fuadi, konteks sosial, sastra sebagai cerminan masyarakat, fungsi sosial sastra.}

\begin{abstract}
The research problem is the structure of the novel's constructor, the social context of the author, the mirror of the society in the novel, and the social function of literature contained in the novel Anak Rantau by Ahmad Fuadi. Ahmad Fuadi's Rantau Anak by using the study of sociology of literature. The purpose of this research is to find out and describe the structure of the novel builder, the social context of the author, literature as a reflection of the community in the novel and the social function of literature in the novel Anak Rantau by Ahmad Fuadi. This research method is a descriptive qualitative method. The data source of this research is the novel Anak Rantau by Ahmad Fuadi. The technique used in collecting research data uses interview and documentation techniques. The results of the research on the novel Anak Rantau by Ahmad Fuadi were greatly influenced by the structure of the novel's builder, the social context of the author, literature as a reflection of society and the social function of literature contained in Ahmad Fuadi's Anak Overseas novel.
\end{abstract}

Keywords - Literary sociology, Ahmad Ridi's novel Anak Rantau, social context, mirror of society, social function of literature.

\section{PENDAHULUAN}

Novel Anak Rantau karya Ahmad

Fuadi berlatar budaya Minangkabau, Bukit tinggi dengan alur cerita pada novel ini bermuatan cerita kekeluargaan, persahabatan, petualangan dan lingkungan hidup. Melalui novel Anak Rantau kita diajak untuk ikut kembali mengembara dan memperoleh pelajaran hidup tidak hanya dirantau yang jauh dari kampung halaman, justru kita dibawa pulang menuju kampung halaman untuk menemukan kembali pelajaran yang hilang.

Novel ini sangat menarik untuk dibaca dan dikaji, pengarang novel ini berusaha membuat alurnya seakan dramatis 
dan persis seperti kisah nyata. Karena, novel Anak Rantau karya Ahmad Fuadi banyak sekali pelajaran dan kebudayaan yang sudah semakin terkikis di era masa kini dapat dilihat pada perkembangan situasi sosial dan masyarakatnya seperti peranan dan tanggung jawab laki-laki Minang dalam tatanan adat dan budaya Minangkabau sebagai tiang dalam tatanan hubungan kekerabatan menurut garis ibu disebut Mamak atau saudara laki-laki dari ibu berfungsi sebagai pelindung satuan kekerabatan Minangkabau.

Berdasarkan penjelasan di atas, penulis melakukan penelitian ini, mempunyai alasan yang kuat dan memilih novel Anak Rantau karya Ahmad Fuadi dijadikan subjek penelitian.yaitu penulis memilih novel Anak Rantau karya Ahmad Fuadi, karena Anak Rantau merupakan novel yang berkaitan dengan struktur pembangun novel, konteks sosial pengarang dalam novel Anak Rantau karya Ahmad Fuadi, dan cerminan kondisi sosial budaya masyarakat Minangkabau dalam novel Anak Rantau karya Ahmad Fuadi, dengan membaca novel ini pembaca dibawa untuk masuk ke dalam alur ceritanya dan belajar sejarah kehidupan yang sangat menarik. Sejarah dikemas secara mendalam, penuh dengan eksotis. Novel Anak Rantau merupakan novel yang berkaitan dengan kebudayaan dan perjuangan serta pendidikan di tanah rantau sampai kembali lagi ke kampung halaman dengan banyak berbagai masalah dalam masyarakat yang berkaitan dengan adat istiadat dan budaya daerah Minangkabau, namun settingnya mengambil sejarah kehidupan masyarakat yang sarat konflik, etnik, dan perjuangan.

\section{METODOLOGI PENELITIAN}

\section{a. Metode Penelitian Kualitatif}

Penelitian ini merupakan jenis metode deskriptif kualitatif. Menurut Aminudin (1990:16), metode deskriptif kualitatif artinya penelitian yang menganalisis bentuk deskripsi, tidak berupa angka atau koefesien antarvariabel. Penelitian kualitatif melibatkan onologis. Data yang dikumpulkan berupa kosakata, kalimat dan gambar yang mempunyai arti (Sutopo, 2002:35).

Objek penelitian ini adalah konteks sosial, sastra sebagai cermin masyarakat, dan fungsi sosial sastra dengan menggunakan kajian sosiologi sastra dalam novel Anak Rantau karya Ahmad Fuadi. Wujud data dalam penelitian ini berupa katakata, kalimat, dan wacana yang terdapat dalam novel Anak Rantau karya Ahmad Fuadi.

\section{HASIL PENELITIAN DAN PEMBAHASAN}

1. Struktur Pembangun Novel Anak Rantau Karya Ahmad Fuadi

Adapun unsur-unsur yang membangun dalam novel Anak Rantau 
Karya Ahmad Fuadi yang akan dibahas dalam penelitian ini adalah tema, alur, latar dan penokohan. sebagai berikut:

a. Tema

Tema yang disampaikan pengarang melalui novel Anak Rantau yaitu tema moral. Tema moral yang di ungkapkan dalam novel ini, yaitu terlihat dari kepribadian Hepi yang mempunyai sifat keberanian dalam menyelamatkan desanya dari jaringan narkoba yang telah meracuni fikiran anakanak muda di kampung Durian Minang. Beruntung Hepi dan temannya berhasil menangkap mereka. Dari penjelasan tersebut bisa disimpulkan bahwa tokoh Hepi menujukkan kepada pembaca novel dalam selipan cerita terdapat pendidikan moral di dalamnya. Terlihat pada kutipan di bawah ini:

"Kejujuran "Kek, aku
sebetulnya sedang
belajar dari kultum
kakek tempo hari.
Kakek bilang sebaiknya
tangan kita selalu di
atas, tangan yang
menolong. Kmi melihat
Mak Tuo Ro situ sudah
tua dan bekerja sendiri
mengurus lapaunya.
Kasihan sekali kami.
Kami menawarkan
bantuan dan dia setuju.
Jadi kami Cuma
membantu, Kek. Kami

ingin jadi tangan di atas." (Fuadi, 2017:93-94)

Berdasarkan kutipan di atas, kutipan "Kakek bilang sebaiknya tangan kita selalu di atas, tangan yang menolong" yaitu Hepi jujur kepada kakeknya kalau dia bekerja di lapau Mak Tuo Ros dan membalikkan nasihat kultum dari kakeknya supaya membantu orang lain tanpa meminta bayaran sepeserpun.

\section{b. Alur (Plot)}

Alur yang digunakan dalam novel Anak Rantau karya Ahmad Fuadi tersebut adalah alur maju karena dalam novel ini menceritakan konflik secara beruntut dan pengenalan tokoh. Tahapan alur dalam novel ini yaitu tahap penyituasian, pemunculan konflik, peningkatan konflik, klimaks, hingga tahap penyelesaian masalah. Dapat digambarkan melalui kutipan di bawah ini:

"Pagi ini Martiaz
tersentak dari mimpi
gara-gara muazin tua
bersin dua kali di
corong pelantang
masjid. Dia merayap
lamban dari balik
selimut dan
meregangkan
badannya yang linu
dari jerih, akibat kurang
istirahat bertahun-


tahun. Sejak dia jadi

perantau. (Fuadi,

2017:5).

Kutipan diatas menunjukkan situasi

dimana Martiaz terbangun dari tidurnya karena mendengar suara seorang muazin tua yang bersin dua kali di corong masjid. Sehingga terpaksa langkahnya terayun ke kamar mandi karena mencium aroma masakan dari dapur.

\section{c. Latar (Setting)}

Menurut Sayuti (dalam Wiyatmi, 2009:40) dalam fiksi latar dibedakan menjadi tiga macam, yaitu latar tempat, waktu, dan sosial. Latar tempat berkaitan dengan masalah geografis. Di lokasi mana peristiwa terjadi, didesa apa, kota apa, dan sebagainya. Latar waktu berkaitan dengn masalah waktu, hari, jam maupun historis. Latar sosial berkaitan dengan kehidupan masyarakat. Latar memiliki fungsi untuk memberi konteks cerita. Oleh karena itu, dapat dikatakan bahwa sebuah cerita terjadi dan dialami oleh tokoh di suatu tempat tertentu, pada suatu masa, dan lingkungan masyarakat tertentu.

\section{d. Penokohan}

Tokoh novel Anak Rantau karya Ahmad Fuadi, terbagi dalam 31 bagian yang mengisahkan tokoh-tokohnya. Tokoh Hepi merupakan tokoh utama yang medapatkan banyak pemunculannya dibandingkan dengan tokoh lainnya.Akan tetapi, tokoh satu dengan yang lain sangat berkaitan satu sama lain dalam membentuk sebuah karya sastra pada bagian cerita. Novel Anak Rantau Karya Ahmad Fuadi menggambarkan kehidupan tentang makna rantau yang terjadi dalam masyarakat adat Minangkabau khususnya laki-laki Minangkabau serta kehidupan sehari-hari sesuai dengan kenyataan yang ada di tanah Minangkabau dalam masyarakatnya.

1. Konteks Sosial Pengarang Dalam Novel Anak Rantau Karya Ahmad

Fuadi

a. Biografi Pengarang

Data-data tentang pengarang yang diperoleh dalam penelitian ini bersumber pada beberapa media berita, media sosial, dan buku yang menjelaskan tentang biografi pengarang. Data-data tersebut meliputi : latar belakang keluarga, pendidikan pengarang, hasil karya beserta penghargaan yang pernah diperolehnya dan proses kreatif penulisan novel Anak Rantau.

1) Latar Belakang Keluarga

Fuadi sangat gemar membaca buku karena diberikan kebebasan untuk membaca di ruangan yang penuh dengan buku-buku. la kemudian menyukai bukubuku karya Karl May, Enid Belyton serta serial album cerita ternama. Semuanya menanamkan banyak latar belakang cerita yang ia kembangkan hingga sekarang. Terlihat sangat jelas bahwa lingkungan keluarga sangat berpengaruh terhadap 
perkembangan anaknya, dari sinilah Fuadi bisa mengembangkan pikiran dan imajinasinya untuk dituangkan dalam sebuah karya yang dapat bermanfaat bagi orang banyak. Berawal dengan melihat kebiasaan dalam keluarga maka Fuadi dapat tumbuh besar menjadi seorang penulis yang tidak diragukan lagi hasil karyanya di dunia pengarang serta hasil tulisannya menjadi banyak inspirasi untuk orang lain.

2) Pendidikan

Latar belakang pendidikan seorang Ahmad Fuadi sangat menunjang proses karya-karyanya yang dihasilkan dan pencapaian sebuah kesuksesannya. Dan dapat kita ambil dari berbagai pengalaman Fuadi sebagai orang yang sangat beruntung dan cerdas bisa mendapatkan banyak beasiswa-beasiswa sekolah diluar negri, karena jiwa semangat yang tinggi dan kemauan serta usaha yang mendorongnya dalam diri Fuadi tersebut. Sehingga Fuadi bisa mewujudkan beberapa impiannya selama ini dan membuat bangga kedua orangtua, keluarga dan negara. Apapun bisa terjadi jika Allah sudah meridhoi, jadi jangan pantang menyerah dan putus asa, selalu berfikir positip dengan kemampuan yang kita miliki maka akan terjadi atas izin Allah. Selain itu juga Ahmad Fuadi dalam mata pencahariannya bukan hanya sebagai seorang penulis tetapi la juga menjadi direktur komunikasi di sebuah NGO konservasi The Nature Conservancy sejak tahun 2007 hingga sekarang, yang berpusat di Amerika Serikat. Dan sering menjadi pembicara bahkan pernah diundang menjadi pembicara di berbagai acara internasional di sebuah pertemuan yang berkaitan dengan menulis sebuah karya untuk berbagi ilmu dan kemampuan yang dimiliki kepada orang lain. Kini, Fuadi sibuk menulis, menjadi public speaker, serta mengasuh yayasan sosial untuk membantu pendidikan anak usia dini yang kurang mampu (Komunitas Menara).

3) Hasil Karya dan Penghargaan

Novel pertamanya, Negeri 5 Menara terbit pada tahun 2009 dan disambut pasar dengan baik. Dalam waktu singkat dicetak ratusan ribu eksemplar dan langsung menjadi national bestseller selama beberapa tahun. Menurut catatan Gramedia Pustaka Utama, Ahmad Fuadi sangat sukses menjadi seorang penulis dengan dibuktikan beberapa penghargaan yang ia raih dan dapatkan sudah cukup menjadi bukti bahwa hasil karya sastranya dapat diterima oleh masyarakat yang luas sebagai pembaca dan dianggap sebagai fungsi sosial bagi pembaca. Selain itu juga, adanya sebuah karya yang dihasilkan dilatarbelakangi dari kehidupannya baik keluarga, lingkungan dan masayarakat sehingga dapat mengembangkan kemampuan yang dimiliki oleh seorang Ahmad Fuadi. 
4) Proses Kreatif Ahmad Fuadi.

Karya-karya Ahmad Fuadi menuturkan kisah fiksi yang baik bisa terasa seperti fakta, cerita fakta yang asyik bisa terasa seperti fiksi. Dua hal bertolak belakang ini bisa saling memberi nuansa sesuai porsinya masing-masing. Oleh karena itu, dapat disimpulkan bahwa Ahmad Fuadi merupakan penulis yang baik dan memiliki kelebihan yang sangat luar biasa dalam menghasilkan sebuah karya-karya yang diterbitkan. Dan Fuadi merupakan penulis yang sangat berbeda dengan yang lainnya karena memliki kemampuan yang lebih dalam menyampaikan pesan yang ada dalam karya sastra tersebut sehingga pembaca mudah untuk memahami karya yang dihasilkannya. Selain itu juga, Fuadi memiliki pendapat bahwa "Menjadi kreatif dan orisinal adalah kunci untuk menghadapi perkembangan digital". la menegaskan kemampuan literasi adalah skill yang melatih daya kreativitas.

b. Profesionalitas Kepengarangan.

Ahmad Fuadi merupakan penulis yang profesional, dan banyak menggunakan media yang populer di zaman milenial saat ini untuk menyampaikan apa yang ada dalam pikiran penulis ke pembaca sangat mudah dan hasil karya sastra tersebut dapat dengan mudah dibaca oleh pembaca atau penikmat karya sastra dan yang pasti jangkauannya menjadi luas. Terlebih lagi hasil karya-karyanya diangkat ke layar lebar dan menjadi inspirasi bagi penulis-penulis lainnya bahkan penikmat karya sastra itu sendiri. Terlihat tanggapan masyarakat yang sangat luas sangat baik dan dapat menjadi inspirasi kepada penulis lainnya untuk lebih banyak menghasilkan karya sastra yang lain dengan mengambil tema yang berhubungan dengan dunia fiksi dan fakta bahkan sebaliknya.

c. Pandangan Hidup dan Pemikiran Pengarang

Karya-karya yang dihasilkan oleh Ahmad Fuadi sangat dibutuhkan oleh masyarakat luas baik dari kalangan pembaca maupun masyarakat biasa yang pada umumnya untuk meluruskan pandangan-pandangan terhadap kebudayan yang ada di Indonesia terlihat dalam budaya Minangkabau. Oleh karena itu, Fuadi melalui karya-karyanya memberikan pesan yang bermanfaat untuk pembaca yang disampaikan dalam karya sastranya tersebut. Selain itu juga tentang hubungan sosial dan kemasyarakatan Ahmad Fuadi dapat disimpulkan bahwa memiliki hubungan yang sangat baik secara individu maupun dalam masyarakat secara langsung maupun melalui karya-karyanya.

\section{Sastra Sebagai Cerminan Masyarakat Pada Novel Anak Rantau Karya Ahmad Fuadi}

Novel Anak Rantau mengambil setting di Jakarta dan kampung Tanjung Durian Minangkabau. Dengan demikian, 
unsur-unsur sosial yang tercermin pada novel Anak Rantau karya Ahmad Fuadi dan kondisi sosial budaya masyarakat Minangkabau yang tercermin dalam novel Anak Rantau Karya Ahmad Fuadi terjadinya setelah beberapa masalah-masalah dalam kehidupan masyarakat kampung Tanjung Durian muncul ke dalam cerita.

\section{a. Terjadinya Peristiwa Pemerintah \\ Revolusioner Republik Indonesia (PPRI) Tahun 1958 Di Padang Sumatera Barat.}

Sebagaimana telah diketahui bahwa peristiwa PRRI tahun 1958-1961 menyisakan trauma kemanusian yang mendalam bagi masyarakat Sumatera Barat/Minangkabau. Bukan hanya korban jiwa dan harta yang tidak terhitung jumlahnya, tetapi juga dampak psikologis. PRRI dicap sebagai gerakan pemberontakan dan dianggap sebagai pembawa nasib buruk bagi rakyat Sumatera Barat. Kekalahan PRRI berarti penderitaan dan penghinaan yang tak alang kepalang besarnya. Harga diri orang Minangkabau diinjak-injak dengan cara yang tak dapat mereka terima. Keadaan ini bahkan berlangsung untuk waktu yang lama, hingga 40 tahun kemudian saat orde reformasi digerakkan oleh orangorang muda. Dapat dilihat pada kutipan di bawah ini:

"Mungkin bukan adat, mungkin bukan orang, tapi mungkin salah sejarah. PPRI tahun

1958 itu sudah

melemahkan orang

Minang. Kita kena

sindrom kalah perang.

Kita sudah sama-

sama tau, banyak

surau yang kosong

sejak itu karena

generasi muda lari ke

hutan dikejar tentara

pusat. (Fuadi, 2017:96)

Berdasarkan kutipan di atas dapat menarik kesimpulan bahwa sebuah karya sastra itu lahir dari berbagai masalahmasalah yang terjadi dalam kehidupan serta tidak lepas dari sejarah yang melatarbelakangi kehidupan masyarakat tertentu. Nilai Patriotisme dalam membela bangsa dan negara sungguh sangat tepat diberikan kepada mereka. Patriotisme berangkat dari nilai-nilai yang sudah terkandung dalam sikap bangsa Indonesia terhadap tanah airnya.Patriotisme sudah mengemuka sejak kisah-kisah kepahlawan bangsa atau bagian dari bangsa yang berwujud perlawanan fisik bersenjata, bahkan perlawanan dengan kekuatan berpikir terhadap pihak-pihak yang ingin menguasai dan memaksakan kehendak kepada eksistensi bangsa Indonesia. 
b. Fakta-Fakta Sejarah Keberadaan Islam di Minangkabau

Sesuatu yang membuat adat dan budaya Minangkabau menjadi khas merupakan satu-satunya dijagad ini, adalah kaitannya dengan landasan adat basandi syaraq, syaraq basandi kitabullah (adat bersendikan agama islam) (Latief, 2002:66).

Dengan masuknya agama Islam ke Ranah Minang, telah terjadi suatu penyesuaian yang mulus sampai sekarang. Berdasarkan fakta sejarah tersebut, kehadiran Islam bagi masyarakat Minangkabau merupakan suatu rahmat, karena dengan ajaran Islam adat Minangkabau semakin kokoh dan sempurna terutama dalam menjalankan kehidupan sehari-hari di masyarakat, Dapat dilihat pada kutipan di bawah ini:

"Dan Datuk manggutmanggut dan tiada alasan untuk tidak tersenyum kepada preman yang tampak insyaf ini. Datuk membatin, inilah orang Minang itu. Mereka boleh tersesat, tapi akan kembali ke surau juga. Mereka boleh jadi penjahat, tapi akan marah kalau dibilang kafir. Nasihat orang tua di kampung sudah $\begin{array}{ll}\text { menembus } & \text { alam } \\ \text { bawah } & \text { sadar }\end{array}$ mereka:"Hidup berakal, mati beriman". (Fuadi, 2017:85)

Berdasarkan kutipan di atas dapat disimpulkan bahwa Al-Qur'an bagi orang Minang merupakan konstitusi tertinggi bagi budaya dan masyarakat. Karenanya tidak masuk akal jika ada orang Minang yang tidak beragama selain Islam. Dan tidak pula keliru menyebut bahwa orang Minang yang pindah agama tidak lagi berada dalam koridor keMinangkabauannya. Karena itu aib besar bagi seorang Minang dikatakan tidak beradat dan tidak beragama.

\section{c. Budaya Atau Kebiasaan Masyarakat Minangkabau}

Bagi orang Minang budaya merantau adalah sebuah anugerah karena bakat perantau yang ulung, Budaya merantau berkaitan erat dengan cita-cita mewujudkan masyarakat yang harmonis antaretnis, menyangkut masalah kesatuan dan persatuan bangsa. Bagi laki-laki Minang merantau erat kaitannya dengan pesan nenek moyang Karatau madang baguni balun (anjuran merantau kepada laki-laki karena dikampung belum berguna). Dapat dilihat pada kutipan di bawah ini:

"Attar selalu bercita-cita merantau dan 


mengagumi orang
rantau. Bagi dia, Hepi
adalah gambaran
impian diri dia kelak,
tinggal di Jakarta,
menikmati semua
kehebatan tanah
rantau. Dia suka sekali
dengan pepatah
kampungnya yang
menyuruh anak muda
merantau untuk belajar
hidup, bahkan ketika di
kampungya dia belum
berguna betul.

Kerantau madang di hulu

Berbuah berbunga

belum

Merantau bujang

dahulu

Di kampung berguna

belum

(Fuadi, 2017:27--28)

Berdasarkan kutipan-kutipan di atas dapat ditarik kesimpulan bahwa masyarakat Minang memiliki tradisi unik, yaitu merantau. Seorang pria yang telah dewasa harus pergi ke wilayah lain untuk menjalani kehidupan atau mencari pengalaman. Tradisi ini dianggap akan menempa anak untuk dapat mengatasi segala kesulitan hidup yang akan dialaminya di masa mendatang. Tradisi ini juga yang menjadikan masyarakat Minang lebih gigih dalam bekerja serta memperjuangkan peningkatan perekonomian.

3. Fungsi Sosial Sastra Novel Anak Rantau Karya Ahmad Fuadi.

Adapun pembahasan fungsi sosial sastra novel Anak Rantau ini dilakukan berdasarkan teori yang telah dikemukakan Watt (dalam Damono, 2009:4) pada bab II bahwa di dalam sastra bertugas sebagai penghibur belaka: dalam hal ini, gagasan "seni untuk seni", yang dari satu segi bisa dianggap sebagai upaaya untuk sepenuhnya hanya menghibur, tak ada bedanya dengan praktik melariskan dagangan untuk mencapai tahap best seller serta sastra mengajarkan sesuatu dengan cara menghibur.

Oleh karena itu, fungsi sosial sastra dapat dibedakan menjadi dua yaitu sastra dapat memberikan Pendidikan melalui nilainilai tertentu dan memberikan hiburan kepada masyarakat (pembaca), Sehubungan dengan hal tersebut dengan hal tersebut, fungsi sosial dalam penelitian ini akan dibahas berdasarkan pada kajian tekstual dari pembahasan fungsi sosial sastra yang didasarkan pada hasil penelitian. 


\section{SIMPULAN}

Berdasarkan uraian pembahasan pada bab IV, maka dapat disimpulkan bahwa analisis sosiologi sastra terhadap novel anak rantau karya ahmad fuadi Dihasilkan kesimpulan konteks sosial pengarang, sastra cermin masyarakat, fungsi sosial pada novel Anak Rantau karya Ahmad Fuadi.

Pada novel Anak Rantau karya Ahmad Fuadi terdapat tema moral pada novel digambarkan sangat jelas nilai moral secara menyeluruh dan memiliki amanat yang sangat luar biasa berguna bagi kehidupan sehari-hari, pengarang dalam menyampaikan amanat melalaui hasil karya sastranya tepat sasaran kepada pembaca karena banyak pelajaran berharga yang dapat di ambil dalam cerita novel tersebut.

Konteks sosial pengarangnya, peneliti meninjau dari segi latar belakang keluarga Ahmad Fuadi dianggap mempengaruhi cerita pada novel Anak Rantau. Terbukti pula dengan ideologiideologi pengarang dalam melahirkan karyanya. Ahmad Fuadi lahir pada tanggal 30 Desember 1972 di Nagari Bayur, Maninjau, Sumatra Barat. Semasa hidupnya, Ahmad Fuadi pernah menulis beberapa buku, baik fiksi maupun non fiksi, dan salah satunya adalah novel Anak Rantau. Adapun ciri karyanya adalah (1) menjadikan sebuah pepatah sebagai satu pengembang cerita; (2) mengandung nilai Islam; menggunakan simile; (4) bercerita tentang anak Minangkabau.

Sastra sebagai cerminan masyarakat Minangkabau pada novel Anak Rantau meliputi: Terjadinya Peristiwa Pemerintah Revolusioner Republik Indonesia (PPRI) Tahun 1958 Di Padang Sumatera Barat, Fakta-Fakta Sejarah Keberadaan Islam di Minangkabau, dan Kondisi Sosial Budaya Yang Tercermin di Masyarakat Minangkabau.

Fungsi sosial terdapat nilai-nilai pendidikan yang berguna bagi pembaca, di antaranya yaitu: (1) nilai pendidikan religius, yang meliputi: rasa syukur dan iklas, (2) nilai pendidikan moral, yang meliputi: kejujuran, rela berkorban, kerja keras, rasa syukur, (3) nilai pendidikan sosial, yang meliputi: saling membantu sesama, toleransi, rasa terima kasih. Dintinjau dari fungsi hiburan, novel tersebut memiliki keindahan cerita keindahan bahasa, dan suspense atau tantangan cerita.

\section{DAFTAR PUSTAKA}

Abdulsyani. 2007. Sosiologi Skematika, Teori, dan Terapan, Jakarta: PT, Bumi Aksara

Agustini, Sri. 2010. Kajian Sosiologi Sastra dan Nilai-Nilai Religius dalam Novel $\mathrm{Ku}$ Hapus Namamu Dengan Namanya Karya Taufiqurrahman. Universitas PGRI Palembang 
Aminuddin. 2014. Pengantar Apresiasi Karya Sastra. Bandung: Sinar Baru.

Arikunto, Suharsimi. 1998. Prosedur Penelitian Suatu Pendekatan Praktik. Jakarta: PT. Rineka Cipta.

Aziez, Furqonul dan Hasim Abdul. 2010. Menganalisis Fiksi Sebuah Pengantar. Bogor: Ghalia Indonesia.

Damono, Sapardi Djoko. 2009. Sosiologi Sastra Pengantar Ringkas. Ciputat: Editum.

Endraswara. Suwardi. 2011. Metodologi Penelitian Sastra. Jakarta: PT. Buku Seru.

Faruk. 2010. Pengantar Sosiologi Sastra Dari Strukturalisme Genetik Sampai Post- Modernisme. Yogyakarta: Pustaka Pelajar.

Febriana, Rina. 2017. Analisis Sosiologi Sastra Terhadap Novel Bulan Terbelah Di Langit Amerika Karya Hanum Salsabiela Rais Dan Rangga Almahendra. Universitas PGRI Palembang.

Fuadi, Ahmad. 2017. Anak Rantau. Jakarta: PT Falcon.

Hafidhah, Nurul, Wildan, dan Sa'adiah. 2017. Analisis Nilai Budaya Dalam Novel Lampuki Karya Arafat Nur, (Online), ( http://www.jim.unsyiah.ac.id, diakses 25 November 2018).

Ismael, Sudirman. 2007. Arsitektur Tradisional Minangkabau Nilai-Nilai Budaya Dalam Arsitektur Rumah Adat. Padang: Bung Hatta University Press.

Jabrohim. 2003. Metodologi Penelitian Sastra. Yogyakarta: Hanindita Graha Widia.
Junus, Umar. 1986. Sosiologi Sastra Persoalan Teori Dan Metode. Kuala Lumpur: Dewan Bahasa Dan Pustaka Kementrian Pelajar Malaysia.

Koentjaraningrat. 1986. Pengantar IImu Antropologi.Jakarta: Aksara Baru.

Kokasih. 2011. Ketatabahasaan dan Kesustraan Cermat Berbahasa Indonesia. Bandung: Yrama Widya.

Latief, H.Ch.N.dkk. 2002. Etnis dan Adat Minangkabau Permasalahan dan Masa Depannya. Bandung: Angkasa.

Mawardi. 2012. Kajian Sosiologi Sastra Dalam Novel Ayat-Ayat Cinta dan Dalam Migrab Cinta (The Romance) Karya Habiburrahman El Shirazy. Universitas PGRI Palembang.

Marta, Suci. 2014. Konstruksi Makna Budaya Merantau Di Kalangan Mahasiswa Perantau. (Online). (http://jurnal.Unpad.ac.id. Diakses 25 November 2018).

Nurgiantoro, Burhan. 2010. Teori Pengkajian Fiksi. Yogyakarta: Gadjah Mada University Press.

Pohan, Rusdin. 2007. Metodologi Penelitian Pendidikan. Yogyakarta: Lanarka Publisher.

Purwanto. 2008. Sosiologi Untuk Pemula. Yogyakarta: Media Wacana.

Ratna, Nyoman Kutha. 2009. Paradigma Sosiologi Sastra. Yogyakarta: Pustaka Pelajar.

Ratna, Nyoman Kutha. 2011. Teori, Metode, dan Teknik Penelitian Sastra dari Strkturalisme Hingga Postrukturalisme Perspektif 
Wacana Naratif. Yogyakarta:

Pustaka Pelajar.

Ratnasari, Dwi. 2015. Analisis Sosiologi Sastra dalam Novel Purnama Kingkin Karya Sunaryata Soemardjo, $\quad$ (Online). (http://download.portalgaruda.org/ar ticle.php. Diakses 25 November 2018).

Ritzer, George. Douglas J. Goodman. 2011. Teori Sosiologi Modern. Jakarta: Prenada Media Group.

Semi, Atar. 1993. Metode Penelitian Sastra. Bandung: Angkasa.

Tim Penyusun. 2002. Kamus Besar Bahasa Indonesia. Jakarta: Balai Pustaka.

Siswantoro. 2010. Metode Penelitian Sastra: Analisis Psikologi. Surakarta; Muhamadiyah University Press.

Sudjiman, Panuti. 1990. Memahami Cerita Rekaan.Jakarta: Pustaka Jaya.

Supardan, Dadang. 2011. Pengantar IImu Sosial: Sebuah Kajian Pendekatan Struktural. Jakarta: Bumi Aksara.

Sutopo, HB. 2006. Metodologi Penelitian Kualitatif: Teori dan Aplikasinya dalam Penelitian. Surakarta: Sebelas Maret University Press.

Stanton. Robert. 2007. Teori Fiksi. Yogyakarta: Pustaka Pelajar.

Thahar. H. E. 2008. Kiat Menulis Cerita Pendek. Bandung: Angkasa.

Warren, Rene Wellek Austin. 2016. Teori Kesusastraan. Jakarta: PT Gramedia Pustaka Utama.

Wiyatmi. 2009. .Pengantar Kajian Sastra. Yogyakarta: Pustaka. 